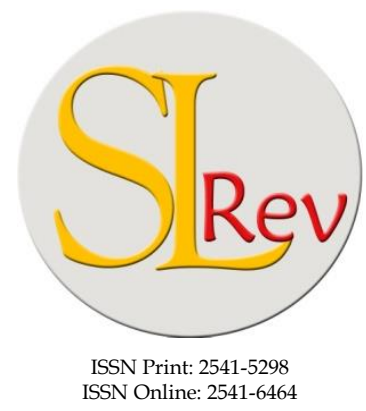

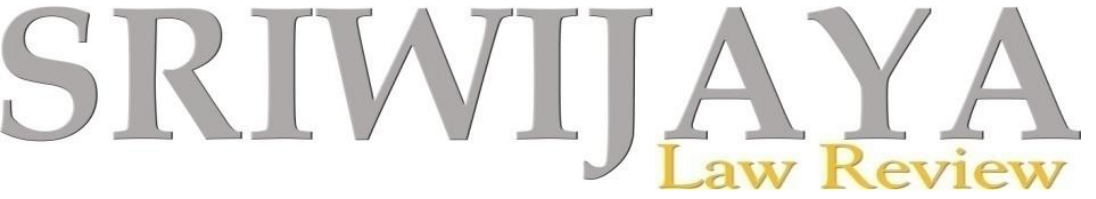

Editorial Office: Faculty of Law, Sriwijaya UniversityJalan Srijaya Negara, Palembang, South Sumatra 30139, Indonesia. Phone: +62711-580063Fax: +62711-581179

E-mail: sriwijayalawreview@unsri.ac.id| sriwijayalawreview@gmail.com Website: http://journal.fh.unsri.ac.id/index.php/sriwijayalawreview

\title{
The History of Forensic Linguistics as an Assisting Tool in the Analysis of Legal Terms
}

\author{
Houtman $^{*}$ and Suryati ${ }^{*}$
}

\begin{abstract}
One dimension of human life which become the issue and had been debated is about the used of legal terms which is against the language rules. The use of language and law are often oriented to non-substance issues, namely the used of formal legal terms which is inconsistent with the standard of the Indonesian language. As a result, such a linguistic study does not provide a functional and proportional impact in resolving the problems of the law itself. The study only becomes as an analysis report on the forms of error in the use of language in the realm of law which is expected to be a feedback for improving the quality of the language of law enforcement officers. Accordingly, the empowerment of forensic linguistics as a tool to solve the legal problems becomes important and made a choice in the field of science, especially in the universities. The various cases developing both in domestic and foreign countries have absolutely proven beneficial for forensic linguistic analysis. A lawsuit that comes from speech and transcribed in written language can be a preliminary proof the reporters used. This is also become complaint to the Police. The article examines whether forensic linguistics can be inferred unlawful speech.
\end{abstract}

Keywords: Courses; Forensic Linguistics; Innovation; Legal Issues.

\section{ARTICLE HISTORY:}

\section{DOI: 10.28946/sIrev.Vol2.Iss2.135.pp215-233}

Received: Jun 13, 2018;

Reviewed: Jul 13, 2018;

Accepted: Jul 31, 2018;

Published: Jul 31, 2018;

Citation: V.2.2 SLRev. 2018.

Faculty of Teacher Training and Education, PGRI University of Palembang, Indonesia. Email: houtman03@yahoo.co.id; suryatilasnai@gmail.com

\section{INTRODUCTION}

In the International seminar held by the Linguistic Society of Indonesia (MLI) in Universitas Pendidikan Indonesia, Bandung in 2011, Forensic linguistics was quite warmly spoken at that time. This branch of science is considered new to be applied in
Indonesia as an effort to assist the government in solving the existing legal problems. Unfortunately, further development of these disciplines has not currently been followed up thoroughly and comprehensively. Particularly a few universities are interested to elevate the field of forensic studies into a branch of science that is paired with linguistics.

Until the end of 2014, there were quite a lot of legal issues that basically touched and involved linguistic analysis. Some of these will be discussed further in the discussion section of this paper.

The Discipline of Forensic Linguistics has a high accuracy ability to detect lies in revealing various cases of criminal acts of 
corruption to criminal. Commissariat chairman of the Linguistic Society of Universitas Pendidikan Indonesia (UPI), Azis, stated that "The structure of someone's language is always standard and the science of Forensic Linguistics is highly scientific and can be learned. Until the field of science is convinced to be able to detect the lie information created when a person is undergoing the examination report."

This paper is a documentation study on the results of research and thought of researchers both from domestics and foreign countries interested in analyzing the existence of forensic linguistics in the legal field of work. UPI is an institution of higher education that pioneered the forensic linguistic work in Indonesia. According to its name, forensic science seeks to uncover the nature of the cause of the case. Through forensic science, the root cause of the real problem which triggers the case to be found. Forensic linguistics as one of the forensic science branches provides as clear as possible the nature and meaning of language speech expressed by a native speaker, in the context of the occurrence of the utterance. This science provides a contribution to the disclosure of the truth of judicial cases in court. As long as the proof of truth is necessary to be done through linguistic data analysis, that is where the forensic linguistics will find its function as one of the analytical tools.

The research working area involves the following forensic linguistics as follows: ${ }^{1}$

1. Voice identification (for instance, determining whether the voice on a threatening tape recording was that of the de-

\footnotetext{
${ }^{1}$ http://www.languageandlaw.org/forensic.htm, (retrieved: January 27, 2015).
}

fendant; sometimes also called forensic phonetics);

2. Author identification (determining who wrote a particular text by comparing it to known writing samples of a suspect; sometimes also called forensic stylistics);

3. Discourse analysis (analyzing the structure of a writing or spoken utterance, often covertly recorded, to help determine issues such as who introduces the topics or whether a suspect agrees to engage in a criminal conspiracy);

4. Linguistic proficiency (did a suspect understand the Miranda warning or police caution?);

5. Dialectology (determining which dialect of a language a person speaks, usually to show that a defendant has a different dialect from that on an incriminating tape recording as opposed to voice identification, which analyzes the acoustic qualities of the voice, dialectology uses linguistic features to accomplish similar goals);

6. "Linguistic origin analysis" (this is our term for the process of trying to determine what a person's native language is, often for purposes of granting or denying applications for political asylum. A more common term is "language analysis," but that term seems too broad. Note that linguistic origin analysis is very similar to what we might call forensic dialectology);

7. "Linguistic veracity analysis" (again, I think I may have invented this term, but it refers to various linguisticallyinspired methods for determining whether a speaker or writer was being truthful).

From the quotation above, it appears 
that the field expertise and research of forensic linguistics included voice identification, author identification, discourse analysis, language proficiency, dialectology, linguistic origin analysis, and linguistic truth analysis:

1. Voice identification (For example, determining whether the sound on the tape is threatening is that the defendant, sometimes also called the forensic phonetic);

2. Author identification (Determining who wrote a particular text by comparing it with the writing sample that known by the suspect, sometimes also called a forensic style of language);

3. Discourse analysis (Analyzing the structure of written or oral speech, often recorded, to help determine problems such as those that introduce the topic or whether a suspect agrees to engage in a criminal conspiracy);

4. Language proficiency;

5. Dialectology (Determining the language dialect of a person speaking, usually to indicate that the defendant has a dialect different from the one on the aggravating record. Differently, from the sound of identification, which analyzes the sound acoustic quality, dialectology uses linguistic features to accomplish the same goal);

6. Linguistic origin analysis (This term for a process tries to determine what a person's native language is. A more general term is "language analysis". Note that the analysis of linguistic origin is similar to what we call forensic dialectology);

7. Linguistic truth analysis (This term refers to various inspired linguistic meth- ods to determine whether a speaker or writer is telling the truth).

Some major cases such as the judicial history of countries, for example, the United Kingdom, the United States, and Australia used the results of the forensic linguistic analysis. As an example of the case of the Aborigines in Australia who were charged with murder. After the sentence, a forensic linguistics presented new evidence proposing an analysis of the structure of the aboriginal language. It was true after the retrial verdict in contrast to the real facts, so that the punishment of the aboriginal person was revoked. ${ }^{2}$

In Indonesia, forensic linguistic studies have existed, but the utilization of the results of the analysis has not been optimal, it seems to be still very sporadic. Perhaps because our laws have not accommodated and made the testimony of linguists as a binding evidence in the judiciary. Therefore, the existence of the Language Center should be felt by the wider community by providing a much greater role. In the Language Center, there are the experts in various branches of linguistic discipline, that need to be coordinated, touched with policy, and coaching for the development of this forensic linguistics.

On the basis of the description above, the main issue to be discussed in this paper concerns the role of linguistics as a tool to solve the legal problems. In this context, the linguistic work area enters the forensic linguistic domain. Furthermore, in relation to the development of science, forensic linguistics will also be discussed from the application side as one of the linguistic subjects in the institutions of higher education.

\footnotetext{
${ }^{2}$ Veven Sp. Wardhana, Bahasa Hukum Bahasa tak Pasti, Tempo, 4 April 2011.
} 
The study in this paper is just an introduction to the phenomenon of law enforcement of Indonesian law and language learning that utilizes forensic linguistic analysis. For additional information, a case analysis of "predictions" of contempt and defamation will be presented.

\section{RESEARCH METHODS}

The research method uses a module covering research ethics, data collection, qualitative and quantitative research traditions, and literature review.

\section{ANALYSIS AND DISCUSSION About Forensic Linguistic}

The term of forensic linguistic first appeared in 1968, when a linguistics professor, Jan Svartvik, used it in the context of reviewing the statements of Timothy John Evans, a Wales truck driver who was sentenced to death by a British court on the alleged murder of Geraldine Evans, a 13month-old baby girl who was his own daughter. $^{3}$

The word forensic is based on the Latin word of forèns(is), which means 'related to the forum or public'. Morphologically, the word forens(is) is formed by the word of the forum that loses its final syllable when combined with a suffix of inflection-ensis. The forum word itself means 'public place or public'. In Indonesian language), The word of forensic is understood in its most recent and highly specialized meaning: 'the branch of medical science related to the application of medical facts to legal matters' and 'surgical sciences relating to the determination of the identity of a person's corpo-

\footnotetext{
${ }^{3}$ Wahyu Adi Putra Ginting. Where Is Our Linguis(tic) Forensic?, 19 March 2012, Available from: http://lidahibu.com/2012/03/19/mana-dimana-linguistik-forensik-kita/ (retrieved: January 30, 2015).
}

rate in connection with the judicial and justice'. The meaning of the forensic word contained in the fourth edition of KBBI is narrow because KBBI exclusively connects forensic with medical and surgical science. In fact, the core meaning of forensic is 'in relation to judicial and justice'; about what has to do with the judicial and justice can be anything. In addition, one of the things that can be possible that is linguistics. Forensic linguistics is one of the many branches of linguistic science. It falls into the category of applied linguistics, which means, forensic linguistics is a manifestation of the application of linguistic science in the field or the realm of legal and judicial and justice. ${ }^{4}$

Forensic Linguistics experts provided evidence in:

1. Trademark dispute and other intellectual property.

2. Dispute the meaning and use of anonymous text writer identification (such as threat letter, textphone, email).

3. Identify cases of plagiarism.

4. Reconstruct mobile text conversations and a host of other issues.

The study of forensic linguistics is still fairly new. However, it reaches the level of the establishment as a discipline in the realm of academic and professional. In 1993, a professional association for forensic linguists established The International Association of Forensic Linguists. A year later, in 1994, an authoritative journal entitled International Journal of Speech, Language, and the Law was created. To date, there are at least three universities offering master's degree programs in forensic linguistics: two in the United Kingdom (Aston dan Cardiff Universities) and one in Spain (Pompeu

\footnotetext{
${ }^{4}$ Wahyu Adi Putra Ginting, Note 3, p1.
} 
Fabra University). A professional forensic linguist can be summoned and asked for his views as an expert witness in a trial requiring linguistic analysis of the evidence or material relating to the case being held. ${ }^{5}$

In the investigation process, the forensic linguist can barely assist the investigation team to perform, for example, a phonetic analysis on a recording of a conversation. On many occasions, phonetic analysis can be used to identify (owner's) sounds. For another case, an example of the case of writing plagiarism, stylistic can be used to prove whether a work is a plagiarism product because stylistic is able to examine the level of similarity style of the writing between each other. On a further level, a forensic linguist can even cancel the verdict that has been imposed by a court on the defendant if the person can prove clearly, through the analysis of pragmatic on recordings and/or the transcription of the interrogation, for example, the defendant is interrogated by an interrogator to admit the act which the person did not actually do.

\section{Legal Language, Uncertain Language}

In Tempo Magazine, on 4th April 2011, Veven Sp. Wardhana ${ }^{6}$ wrote: Law, which has the feature of 'definite' meaning, it appears opposite because of the language factor. Variety of legal language is a variety of standard languages that have the quality of certainty that should be telling, no miscellaneous, and no ambiguous. The variety of legal language is a manifestation of morphosyntax engineered in such a way that the meaning produced by the variety of languages can be understood by all speakers as a meaning. In short, there is no possibility

\footnotetext{
${ }^{5}$ Wahyu Adi Putra Ginting, Note 3, p5.

${ }^{6}$ Veven Sp. Wardhana, Note 2.
}

of any other meaning in the variance of the law. It is the requirement and it is not negotiable.

Nonetheless, in practice, the idea that has been mentioned above is often unfulfilled. This is what Venven discussed with quite succinct but eye-catching reason. Veven provided an example of a law in which common coercion occurs as a reward for the uncertainty arising from the pattern of meaningless sentence formation. Veven's example: Law No. 1/1974 about marriage ${ }^{7}$, article 2, paragraphs 1 and 2 as follows:

"(1) Marriage is lawful if done according to the laws of their respective religion and belief; (2) Each marriage shall be recorded in accordance with applicable laws and regulations."

It is obvious that the two verses may be separated (note the numbering (1) and (2) that are being used) and may be joined together (note the use of the semicolon ';'). When these two verses are understood separately, that means the first verse is sufficient to define a legitimate marriage (note the word if, which is a marker of the validity of a marriage). In this case, marriage based on a religion will be considered legitimate without the need to register it legally. The problems will arise when disputes occur in the household because the marriage book is considered to be "an essential point of the lawful document". ${ }^{8}$

\section{The Role of Forensic Linguistics in Indo- nesia}

In Indonesia, Forensic Linguistics exists but the utilization of the results of the analysis

\footnotetext{
${ }^{7}$ Nurhidayatuloh., et all, 2003, "Perkawinan di Bawah Umur Perspektif HAM-Studi Kasus di Desa Bulungihit, Labuhan Batu, Sumatra Utara.” Jurnal Al-Mawarid, p1-14.

${ }^{8}$ Veven Sp. Wardhana, Note 3, p8.
} 
are not optimal, it seems it is still very sporadic. Perhaps, it results from our laws which are not accommodated and made the testimony of linguists as binding evidence in the judiciary.

Forensic Linguistics Studies in Indonesia has not been developed optimally. Assuming that it is being used, it could help reveal cases of corruption or other criminal cases. Forensic linguistics detects lies through the analysis of the acknowledgment of the suspect's statements and witness in terms of the language used. One method of Forensic Linguistics is through interviewing techniques. "The interview technique used can be compared with the examination of the police investigation report. Accompanying Forensic Linguistics, all information given by a person can be analyzed with linguistic structure".

Aminudin stated that if there is a different result between the Forensic Linguist and the police investigation report, there can be something wrong. Either there is engineering in the police investigation report or because the method of Forensic Linguistics is scientifically analyzed and no engineering. "This science can also be investigated by investigators since the language of a person through the information is a reflection of his/her feeling. Therefore, Forensic Linguistics can uncover or explore information on any case, including terrorist cases."

Forensic linguistics deals primarily with the problem of speaker identification based on dialect, speech, or accent, sometimes even analyzing the suspect's handwriting to get his/her profile, matching the recording of the accused with a number of suspects, analyzing the characteristics of a person's voice, making sure that the sound recording is original and not engineered (read Rasti case), as well as filtering and sorting out the various recorded noise to find out the background where the recording was made. All analyses of forensic linguistics experts are taken into consideration in court. Forensic linguists are often consulted as expert witnesses.

When studying forensic linguistics, it is possible that the linguist's expertise in the realm of law is helpful in the process of investigation by the police and it is expected to fully solve the most difficult cases such as case of corruption nowadays.

\section{Acoustic Forensic Assessment}

Today, forensic linguistics studies are specifically applied in the fields related to the language sound system known as phonetics. The role of phonetics, in this case, is directed at the disclosure of personal identity through the sounds of language. This phenomenon is based on the fact that every human being has a language sound that is different from each other.

Susanto, an Indonesian student, managed to find a sound verification technique with the Synchronic Stability Vowel System for the purpose of verification of taped sound tapes as evidence in a trial. This system can be used to verify whether the voice in the recording belongs to the defendant or not. His discovery was presented at the conference of International Association of Forensic Linguists (IAFL) in 2012 in Kuala Lumpur, Malaysia. Two of the experts who attended the conference as Plenary Speaker were Prof. Malcolm Coulthard, a Forensic Linguistics expert of Aston University, United Kingdom and Judge Peter R.A. 
Gray of the Federal Court, Australia. ${ }^{9}$

In the case of Nias, to strengthen its report on allegations of the bribes to the Corruption Eradication Commission, a member of the Election Commission, Saut Hamonangan Sirait, recorded his conversation with the former South Nias Regent, Fahuwusa Laia. To ensure that the recorded voice belongs to Fahuwusa, the Corruption Eradication Commission investigators also use the services of forensic linguistic experts from Bandung Technology Institute. This was revealed in a follow-up trial of the defendant Fahuwusa in Jakarta Corruption Court, J1 HR Rasuna Said, South Jakarta, Tuesday (20/12/2011). The expert witnesses were the linguists of Bandung Technology Institute, Djoko Sarwono. Djoko told that he and the team were asked by the Corruption Eradication Commission investigators about the vote. The investigator showed two samples of voice. One sample was identified and the other one was to be equated.

In conclusion, the two samples had a resemblance of up to 80 percent. Djoko pointed out that if a voice sample had a similarity as much as to that percentage, it was almost positive that the voice was the same. He was sure there was no human being having a very identical sound. The shape of the lips, teeth, chest cavity, the abdominal cavity are what cause the differences in each type of sound. Someone can indeed make a voice similar to someone else. But it takes a long time to practice it. "And usually it is just a minute, and then the person will return to his/her original

\footnotetext{
${ }^{9}$ Eddi Santosa, Students of The Republic of Indonesia Discover Voice Verification System For Forensics, Available from: Detiknews, p2. (retrieved: December 20, 2011)
}

sound," he concluded. Barely to remind, Saut reported that Fahuwusa contributed him a money with the amount of 100 million rupiahs. The money was to annul Ferrywusa's write-off as a prospective regent. Well, to strengthen his report, Saut also recorded his conversation with Fahuwusa in the Corruption Eradication Commission Office. $^{10}$

Commonly, that is just one of the ways in which linguistic forensic works. The problem in Indonesia is that this science is not yet known as an academic discipline; In other words, Indonesian linguistics has not touched the forensic domain. Indonesian Language Dictionary also interprets new forensic limited to the field of medical science and post-mortem. Our judicial and police systems have not recognized and acknowledged linguistic share as one of the methods of producing judgments that may affect court judgment or as a means of investigating cases. In short: forensic linguistics has no authority in Indonesia and most probably has not existed, or very few Indonesian linguists who work as forensics linguists.

The recognition of authority is very important for forensic linguistics because it is the requirement to create this science to be useful. It is useless to have a solid linguistic analysis of legal texts when the analysis itself is not recognized by its influence. Of course, before the Indonesian judiciary and police system recognize the influence of forensic linguistics within their systems, this science itself must academically be strong, merely like the medical science

10 Moksa Hutasoit, Corruption Eradication Commission Presents Linguistic Expert in Bribery Meeting of General Election Commission's Member, Detiknews, p2. 
that is already strong academically so its role and its analysis conclusions are recognized in the field of forensics.

\section{Honesty Tests through Someone's Lan- guage Style}

Who was actually honest and lying in the case of former Democratic Party Treasurer Nazaruddin and the Corruption Eradication Commission? The truth test can actually be revealed using language forensics.

Similar to forensic surgery in medicine, language forensic dissects someone's oral speech that is being transcribed or written. Analysis of this language in a number of countries such as Australia and Europe were used as evidence in the trial.

According to a professor of pragmatic, sociolinguistic, and language philosophy of Universitas Pendidikan Indonesia, Aziz, the way of language surgery is carried out in two ways, namely interviews and investigation report of the litigant. "Language experts can also find out whether the interviews and investigation report maker are honest or not," said the initiator of forensic language in Indonesia in conversation with Tempo magazine, last weekend. ${ }^{11}$

Language specialists analyse the birth structure of language and inner language. The birth structure can be analysed from language constructions and sentences used. Meanwhile, the inner structure is analysed in terms of the meaning of the spoken word. "From the merger, it can be seen whether someone related to the case was certain or not, or hesitant with his words," he said.

The construction of sentences and speaker's choice of words relatively will be consistent with what someone believes, including the use of active, passive, and com-

\footnotetext{
${ }^{11}$ Sanjaya, Tempo, 2011, p9.
}

plex language phrases with many compound sentences. Though the assessment variables are enough, Aminudin said, language analysts can discover a pattern of language consistency that speakers use. "The level of forensic accuracy of this language abroad reaches 80 percent."

The remaining of 20 percent is considered to fail to analyze the people who turned out to have psychological disorders and good at playing the language. "To deceive people, every time someone's speech can change, as a result, the linguist will not be able to find the truth of one's words, probably s/he used to lie since childhood," said the Rector of Universitas Pendidikan Indonesia in the field of planning, research and development.

\section{Some Questions and Sample Cases}

1. In the first case, the police arrested 7 Singlar villagers for allegedly looting the evidence they received from ANTV's report in the Morning Top news segment on November 21, 2010. In the report broadcast, there was a twelve-sentence narrative describing a 'Looting' perpetrated by a 'youth plot' in the Singlar hamlet. The case was sparked by controversy as the suspects of the case did not feel that they committed the looting. This controversy made the people and Wahmuji try to investigate the case. The people's inquiry materials were transcriptions of the twelve-sentence narratives and snippets of ANTV cameraman images broadcasted in the form of the television news product. Using our semantic-contextual analysis it proved that the 'loot' stamp was incorrect to be embedded on the events occurring in Singlar; with the analysis of the meanings and tendencies of the dictionary selection proved that the twelve-sentence narratives produced by the newsmakers had absolutely the 
motive for imaging the people whose images were portrayed as 'looters'; and by comparing the suitability of the images and narrations proved that there were claims of reported events without image proof. ${ }^{12}$

2. Can Status on Facebook be sued?

The status of Facebook containing complaints of injustice, disrespect, and scolding that all never mention the names or agencies can be put on the table. Related to that, based on the Article 27 paragraph (3) in conjunction with Article 45 paragraph (1) of Law No.11 of 2008 on Electronic Information and Transactions ("ITE Law"), it is potential to consider the Facebook content as a criminal act even though it does not clearly mention the complained name or institution. The following is the sounding of Article 27 paragraph (3) of the ITE Law and Article 45 paragraph (1) of the ITE Law.

Article 27 paragraph (3) of the ITE Law:

Every person intentionally and without a right distributes and/or transmits and/or makes accessible Electronic Information and/or Electronic Documents with defamatory and/or defamatory content.

Article 45 paragraph (1) of the ITE Law:

Any Person who fulfils the element as referred to in Article 27 paragraph (1), paragraph (2), paragraph (3), or paragraph (4) shall be sentenced maximum of 6 (six) years imprisonment and/or a maximum fine of $\mathrm{Rp} \mathrm{1,000,000,000.00} \mathrm{(one} \mathrm{billion}$ rupiahs).

Based on the Article 27 paragraph (3) ITE Law, one needs to be careful in writing on his/her Facebook status. This is because the regulation of defamation or contempt in the ITE Law is broader than the Criminal Code

${ }^{12}$ Note 2, p5
(KUHP). In the meantime, in the Criminal Code (Chapter XVI about humiliation) it is obvious that such defamation should be committed against a person and constitute a complaint offense (Article 319 of the Criminal Code). However, the Article 27 paragraph (3) of the Law on ITE is only stated that a person who commits insult or defamation through electronic media may be convicted.

Regarding the defamation article of the ITE Law and the Criminal Code, the Chairman of Indonesian Cyber Law Community (ICLC), Arifiyadi in the article complained in social media by disguising the name of the targeted pointed out that:

Whether a word or phrase is said to defame a person or a legal entity in the Criminal Code ("KUHP") and Law No.11 of 2008 on Information and Electronic witnesses ("ITE Law") is not defined in detail. This is because the meaning of vilification has a relative meaning. To prove more accurately a word or phrase is said to defame a person or institution, the Law Enforcement Official ("APH") usually uses a linguist or other social scientists related to the substance of that word or phrase.

3. Legal for Spread Capture Conversation via Blackberry Messenger (BBM)

Capture in the form of an image to a conversation via Blackberry Messenger $(\mathrm{BBM})$ that is distributed without permission of all parties involved in the conversation may be subject to violations of the articles of the ITE Act. Lately a widely spread of capture is aimed to distribute slander or defamation. In fact, BBM conversations are usually only in a personal context.

The dissemination of private electronic conversations to public areas either through BBM group or individual 
or perhaps by way of dissemination to many recipients freely constitutes a breach of privacy as regulated in The Law No.11 of 2008 on Information and Electronic Transactions ("ITE Law").

In the ITE Act, there are two articles related to possible violations in the spread of the capture of conversation via BBM: First, it is the provision of personal data contained in Article 26 of the ITE Law. If the capture of conversations is via BBM, there are personal data including names, writings, and/or images that can identify a person then the dissemination of the conversation through electronic media either conducted by parties outside the conversation or by any party that is in conversation must be made with the consent the related person. Violation of Article 26 of this ITE Law may be subject to civil sanction.

The following is the overall content of Article 26 of the ITE Law:

(1) Except as otherwise provided by the Laws and Regulations, the use of any information through electronic media concerning the personal data of a person shall be made with the consent of the person concerned.

(2) Everyone whose rights are violated as referred to in paragraph (1) may file a lawsuit for damages incurred under this Act.

Second, it is the provision of defamation. If the dissemination of such conversations through electronic media defames the person's status/reputation/ honour, the party who knowingly disseminates/distributes the conversation without rights or can be interpreted without the consent of the person violates the provisions of Article 27 paragraph (3) of the Act ITE.

The content of Article 27 paragraph
(3) of the ITE Law is as follows:

Every Person knowingly and without a right distributes and/or transmits and/or makes accessible Electronic Information and/or Electronic Documents with humiliation and/or defamatory content.

The violation of the provisions of Article 27 paragraph (3) of the ITE Law is threatened with criminal sanctions as regulated in Article 45 paragraph (1) of the ITE Law which is maximum imprisonment of 6 (six) years and/or a maximum fine of Rp1,000,000,000.00 (One billion rupiah).

Another thing to note related to the capture of BBM is to take into account that the BBM's capture file is an image form, it does not mean if the capture of $\mathrm{BBM}$ is edited or engineered with an image engineering software according to the will of the disseminating party, so it looks as if it was in accordance with the original. No one can guarantee the naked eye that the capture of fuel sent by someone that must be identical to the BBM format as the original. Scientific testing or observation is required (such as via digital forensic methods) to ensure a BBM's capture is genuine (in accordance with the original form and content).

4. Example of PRAGMATIC ANALYSIS OF FAIR ACTION THAT REFLECTED LAW ${ }^{13}$

This study aimed to reveal the alleged speech as a crime of humiliation, deception, and defamation by using Pragmatic analysis. The results of the

13 Andika Duta Bachari, Pragmatic Analysis of Legal Impacts, Research Report, Bandung: Pendidikan Indonesia University, 2012. 
preliminary studies conducted by the authors show that research on the effectiveness of the sentences was an area that most people did in the context of the study of the language used in the realm of law. This study was directed to discuss the issue of speech acts having an impact on the law, namely the alleged speech as an act of deception, humiliation, and defamation. The basis of the belief in the understanding and view of language studies cannot be separated from the socio-cultural realities, and it also accompanies the presence of an event in the language. As a consequence, this study of speech acts having an impact on the law would be studied through a functional approach. This study used a pragmatic theory as a branch of linguistics with the philosophy of functionalism which would be utilized as a theoretical framework for data analysis.

\section{Research Problems}

The law-related speech acts in this study were identified as reported by the reporters to the Detective and Criminal Unit of the Resort Police of Big City (Polrestabes) of Bandung as an act of fraud, defamation, and humiliation. The law-impacted edicts of this study were limited to the speech represented by text (in the form of written language). Thus, this research would endeavor to prove whether or not the reporter's alleged misconduct of the reported act of speech was considered to be a criminal act of fraud, defamation, and humiliation.

\section{About Data and Data Analysis Proce- dures}

The data of this research were the police investigation report to the complainant, the reported, and the persons who were presented as witnesses by the complainant and reported. The witnesses were presented in his capacity as persons who knew of an event that was charged with a specific crime to the police. The police investigation report was prepared as a standard police procedure (read: investigator) when conducting an investigation on a particular case. For the complaints, as the case analyzed in this research, the police would determine whether the complaint complied with the criminal elements as set out in the article or not? Through the minutes of this examination, the police would determine whether or not a particular case has proceeded to court.

The unit of analysis in this research was a speech used as evidence by the complainant as a specific crime. In other words, the unit analyzed was reported in spoken sentences.

In general, the data analysis of this study was conducted in the following steps:

1. Doing anonymization of the names involved in the case as stated in the investigation report. For example, the author anonymized a name as $\mathrm{Mrs} / \mathrm{Mr}$. X, which was the investigation report stated as rapporteur.

2. Describing the legal utterances and identifying the pragmatic component as the context of the birth of the speech, i.e. on all matters relating to speech $(\mathrm{u})$, speaker (s), opponents' saying (h), the context and contexts (c). The description was done by looking at all the information presented by the witnesses in the minutes of the investigation report.

3. Exploring the power of the speech by taking the context into account of the birth of the speech that the author previously described through the contextualization of the case contained in the minutes of the investigation report. 
4. Exploring the conversational implicatures to understand the speaker's intent in delivering the speech.

5. Analyzing the speech to prove the fulfilment of the terms of validity (felicity conditions) in the unit being analyzed (in this case the spoken speech). This analysis examined the matters relating to the authority of a person to say, the sincerity of a person expressing a speech and the impact of the action of the utterance. The term of validity was a linguistic measure to determine and prove that a speech was categorized as a dimension of fraud, humiliation, and defamation.

6. Summarizing the error allegations of fraudulent, defamatory, and defamatory actions in the reported speech imposed by the complainant

\section{Research Findings}

In line with the problems of this study, there were three research findings used as an answer to the problem.

First, the power of speech in the reported speech illustrated the existence of an act which, according to the complainant, contained certain crimes against him/her. Speech power was related to the power of speech implied in giving birth to a particular purpose. The meaning of a speech was not always similar to the words making up the sentence, but it was influenced by the context of the narrative. All reported speech was basically a dimensionless action. In the case of humiliation, the reported speech had power as a form of humiliation. The two reported, (Mrs. X and Mr. S) committed humiliation by evaluating the physical and reporting characteristics of the low and negative categories. In the case of fraud, the reported speech (Mrs. D) had the power of speech as a deceit/lie delivered to direct the opposite of his speech to perform the action reported wants, while another speech (PT $\mathrm{K})$ dimension was as an effort to offer. In the case of defamation, the reported speech (Mr. W) was powerless, it did not acknowledge the circumstances of the complainant, it warned the complainant not to engage in certain activities and evaluated the reporting action as an incompetent person. The three powers of the chorus were difficult to belong to a defamation act.

Second, the conversation implicatures of the reported speech were identified through an analysis of the application of the Cooperative Principle in the speech. In the case of humiliation, the reported speech implicature ( $\mathrm{Ny} \mathrm{X}$ ) was an attempt to end the conversation with the complainant and reply to what the previous complainant said, while in the other case the reported speech implied that the reporter was angry and declared it was problematic because of the previous reporting action which was considered harmful. In the case of fraud, the implication of the speech $\mathrm{Ny}$. D was to deceive the complainant for profit, while the implication of PT. K was not proven to cause harm to the complainant as the main characteristic of a fraud. The implication of the speech in the case of defamation was that the reported party gave a reply with the contents of the judgment of the acts conducted by Mr. R.

The validity of the speech was seen from the felicity conditions to prove that all the reported had the capacity to deliver the speech because of a problem. In addition, the context of the birth of the speech indicated that the reporter said the utterance in earnest, other than it was true that their speech was dimensionless action.

The fulfilment of the terms of validity in the reported speech was helpful to 
prove the unfairness of the alleged complainant against the complaint. The results of the analysis indicated that the 3 reported reports were accurate to be suspected as criminal offenses, while the other two were not appropriate to be suspected as criminal offenses.

Based on the analysis above, it is obvious how important the role of an in-depth study of forensic linguistics is. In recent years, there have been many legal cases of defamation based on their law which has a basis to be charged into the legal domain for the perpetrators. However, highly skillful scientists who have the ability to interpret a conversation are thought to be potentially a form of vilification which is not enough. As a result, interpretation in the judiciary still varies.

Several of these "defamation" issues are described as follows:

\section{Joking in Internet Groups, This Employ- ee Is on Trial}

Civil servants detained for criticizing the Regent Gowa, Ichsan Yasin Limpo, Fadli Rahim (33) was undergoing a follow-up trial at the Sungguminasa District Court on Wednesday (24/12). The hearing was held with the agenda of listening to the memorandum of exception from the defendant.

Fadli's legal adviser, Nursal, said the indictment filed by the public prosecutor in the previous session was odd. The charge of the indictment was deemed unclear and incomprehensible. "In the indictment, the expert witnesses seemed to add the translation of Fadli's conversation in the Line group," he said.

Nursal stated in a conversation in the social media group that Fadli wrote in Makassar language "Jai-jai investor tena anjari proyek". And then by the expert witnesses, it was translated "There were many investors whose projects were cancelled because the Regent did not receive a commission". "Whereas the real meaning, many investors did not build the project. It was obviously exaggerating," he explained.

Nursal also stated that the prosecutor in the indictment of applying the Electronic Information and Transaction Law Article 27 paragraph 3 was considered inappropriate. The article mentioned only the contents of the norm of prohibition. "Not a criminal provision," he said.

Fadli, who was met at the Makassar Detention Centre before the trial, said that the criticism he delivered in the Line group was not intended to humiliate the Regent. Instead, the criticism was a feeling he conveyed as the hope of an ideal government in Gowa District.

"We were just kidding in the group, and I just conveyed my feelings about this area, that's all," he said. He also denied having intentionally defamed the regent by spreading the conversation transcripts in the Line group. "I never spread it, so which one was called defamation?" said the staff of the Department of Culture and Tourism of Gowa Regency.

Meanwhile, the Head of Inspectorate of Gowa Regency, Chairul Natsir confirmed that Fadli was sanctioned demotion and suspension of positions. "I have forgotten what my position was because the case was long enough," he said on Friday (19/12).

Chairul would submit a recommendation letter of dismissal if Fadli was sentenced to prison for six years. "He could have been fired, if the punishment was long enough, we can apply to the Civil Service 
Agency," he said. ${ }^{14}$

\section{People's Torch Be Snared Press Law, Po- lice: Witness Fear}

Public Relations Division Head of Police Headquarters Ronnie F. Sompie said the reason for the use of Press Law to ensnare two suspects in the case of the People's Torch tabloid because the institution was pursued in time. According to Ronnie, the Police had to quickly take action to curb the growing issues in the community. "We are urged by many parties to ensnare the $\mathrm{Peo}$ ple's Torch suspect with the prevailing law, but no criminal law can be imposed on them," Ronnie said when he was met by Tempo at his office on Monday, July 14, 2014. The torch contained a black campaign against the presidential candidate Joko Widodo.

According to Ronnie, the Police arrested the suspect with the Press Law because no experts were willing to be questioned to strengthen the existence of a criminal act in the case of Torch. Ronnie also stated that in order to ensnare the suspect Torch with criminal law, Police need information from linguists, law, and criminal law experts. However, the police did not get any information. "These experts were afraid of having the Witness and Victim Protection Agency if it is necessary for them," Ronnie said.

Consequently, Ronnie described that the Police used the Press Law. He said the Police knew it was special, but it was what the Police could do at that moment. He then explained the problem as follows. The Press Council evaluated that People's Torch was

${ }^{14}$ http://www.tempo.co/read/news/2014/12/26/0586 30981/Bercanda-di-Grup-Internet-Pegawai-IniDiadili (retrieved: January 27, 2015). not the product of the press. "We get confused," as Ronnie said. Ronnie described he did not dismiss if there were likely additional violations of the law in the case of the Torch. According to Ronnie, now there are already some experts who are brave enough to examine this case. "If the study discovered a violation of the criminal code, the two suspects of the People's Torch might have been subject to criminal law articles and arrested," Ronnie concluded. Tuesday, 27 January 2015 | 09:52

The One who insulted Prabowo was Detained for One Month More

Convicted of defamation against former presidential candidate Prabowo Subianto, Brama Japon Janua, 31 years old, chose to undergo an additional one month of detention. Four months in prison by Surabaya District Court yesterday was actually enough to keep him free.

However, another option had to be taken because the judges, headed by Manungku Prasetyo, added to the penalty of a fine of 10 Million Rupiahs subsidiary a month of confinement. Hearing the verdict, Brama, previously being detained as a security guard at the port, answered that he could not pay the fine. "I added another month," he said, after reading the judge's verdict.

The verdict prison is received by Brama in accordance with the previous prosecutor's. It was only the judge's penalty which was greater than the 250,000 rupiahs. "If it is not accepted, an appeal can be submitted," said Manungku.

Brama has been detained at the First Class Detention Center Surabaya since August 5, 2014. He was accused of defaming the East Java Police and Prabowo Subianto because of his Facebook status. 
Claimed as a member of the Brigade Mobile Police, holding the rank of Brigadier Two Policeman in East Java, Candra Tanzil, Brama wrote:

If this country is headed by Special Forces Command (Kopassus), it is unthinkable to me. The fear of evil will be rampant. Oh God, I just want to live in peace, God please create Jokowi as a winner, because I am very confident about Jokowi's leadership if he can become a president of Indonesia.

According to the three news above, there still have something that needs to be discussed more deeply for each case. Considering the first case editorial: An employee of the Tourism Office of Gowa district, Fadli wrote in Makassar native language. "Jai-jai investor Tena Anjari Proyek" then by the expert witnesses, it was translated into "There are many investors whose projects were cancelled because the Regent did not receive a commission". Whereas the real meaning is, "many investors did not build the project".

As a result of these writings, the concerned employee was detained and demoted, as well as the postponement of promotion and even threatened dismissal from the civil servant status. This is obviously very impartial. It also fittingly raised a firm law on the "mandatory" existence of a language expert to provide an interpretation of the occurred event which was said.

Note also in the third case, a young man named Brama put in prison for writing:

If this country is headed by Special Forces Command (Kopassus), it is unthinkable to me. The fear of evil will be rampant. Oh God, I just want to live in peace, God please create Jokowi as a winner, because I am very confident about Jokowi's leadership if he can become a president of Indonesia.

His statement was considered to have insulted Prabowo. Of course, it should not be that easy. Editorial Language is deemed to have qualified as a form of defamation statement. This will not happen if the language analysis conducted forensic linguist working optimally.

The two events above are very different from the incessant contempt against Jokowi. So far, the musicians of the AD quite a lot of statements openly nuanced Jokowi. But until now there has been no significant action. Indeed, this is all back to those who feel slandered. And maybe so far Jokowi has not felt it is a form of humiliation and/or defamation. But it is fitting, law enforcement that leads to verbal evidence both oral and written must be fair. The lack of understanding and the lack of a linguistic forensic technique that makes the interpretation of a statement bias and unclear.

The given such events are frequent and increasingly widespread, so language experts should also consider forensic linguistics as a branch of science developed at universities in view of its high use for the establishment of justice in the country.

However, the legal sanctions provided vary considerably. It is necessary to need a more in-depth review of the subject matter of the law faced, because the issue is about language issues, the involvement of linguists is urgently needed, particularly the ones who have expertise in the field of forensic linguistics.

\section{Forensic Linguistics as a Science Branch in a Higher Education}

Listening from several higher education references in the world which organizes study forensic linguistics, such as Monash University and Aston University can be addressed in a positive few things about forensic linguistics, (hereinafter abbreviated as LF) which can be considered as an alternative to the study of linguistics in higher 
education.

First, the material of science concerns the comprehensive knowledge and understanding of the field of forensic linguistics, which analyzes the language of the legal process. In order to understand how its linguistic analysis, LF can be used as a vital investigation tool. Students will gain a wealth of experience in analyzing language data derived from the context of real-life law. Teachers are expected to use teaching materials from the original case, including from the Forensic Linguistics Case docket itself, ensuring that they will gain the best possible insight into the field and ensure that the program is relevant, up to date, and based on the reality of the professional practice.

Second, Material Selection. The description of the lecture materials containing the main subject of the study is as follows.

\section{Core Material: \\ Introduction to Linguistics}

This material is designed for students who come to the program without previous qualifications or experience in linguistic analysis. It introduces to students the basics of language analysis, equipping them with the necessary knowledge and skills. Students may be advised, whether this module is mandatory or not for them.

\section{Introduction to Forensic Linguistics}

This material provides a general introduction to forensic linguistics, covering key topics in the field. This will provide students with a strong foundation in all key areas, including courtroom discourses, police interviews, language as evidence, the role of linguists as expert witnesses, and language and weaknesses in the legal process. This basic material provides a spring- board for the next elective material, giving students a taste of various available topics.

\section{Analyzing Written and Spoken Discourse} These materials introduce students to understand context-based oral and written discourses. Various approaches of text analysis are looked at such as genre and register, patterns and signals, ethnographic communication, conversation and pragmatic analysis. The approaches are then applied to the analysis of oral and written discourse in various contexts, including non-forensic contexts. These materials allow students to develop their skills in discourse analysis and improve their understanding and awareness so that they will feel more confident about the collection and analysis of oral and written data.

\section{Linguistic Investigation and Evidence}

The introduction of a forensic linguistic investigation and the form of evidence that a practitioner might be expected to provide is introduced. It provides students with an overview of the various possible linguistic evidence and encourages them to explore what should not and should be provided as evidence by linguists. This encourages students to consider the needs of the police and the courts in a written report and linguist role in providing evidence as an expert witness. Examples of real cases need to be given in this course.

\section{Spoken Language and Legal System}

This part takes a deeper view of the oral text in the context of the law. Some of the most important parts of the legal process depend on oral interaction, from initial meetings between police and community members, to witness and suspect interviews, courtroom interactions. It is necessary to analyze all kinds of interactions, 
along with the legal professional language ('police-speaking', and 'speaking like a lawyer'), language offenders and treatment, and a wider consideration of the differences between law and lies paradigm of communication.

\section{Written Language in the Legal System}

It discusses the role of texts written in the legal system. It starts by considering the extent to which the written legal text regulates all our lives, regardless of whether we ever read them or did know where to find them. It is necessary to examine contracts, product warnings, insurance and other consumer documents, as well as laws and other formal legal texts such as judge/prosecutor instruction. The main theme is the issue of comprehensibility and disputed meaning, especially where a layman comes into contact with the text of the law. Other topics include plagiarism and legal language as a genre.

\section{Linguistic Disadvantage in Forensic Con- texts}

It provides students with an introduction to the form of language flaws in forensic and legal contexts. The contexts include the point of arrest, during interview investigations and courtroom interactions. Adverse forms are considered to be non-native speakers, deaf or partial deaf and require interpretation marks, to be vulnerable children or adults. Strategies to address weaknesses include legal interpretation and translation (including signing), intermediaries, and other measures aiming at protecting vulnerable language and psychology.

\section{Career Prospects}

This program is designed for students interested in careers in today's emerging research fields, namely career development opportunities for linguistic and professional researchers in the legal process. In relation to scientific studies in colleges, it is possible that forensic linguistics is proposed as part of applied or stand-alone linguistics as a science.

\section{CONCLUSION}

1. The Language Center should have an important role benefited greatly by many people. The Language Center has experts of various branches of linguistic discipline, living in coordination, touched with policy, and coaching for the development of this forensic linguistics.

2. Given the many problems that occur in the legal and judicial spheres of Indonesia, Indonesian linguists have inevitably paid close attention to efforts to build education and forensic linguistics institutions in Indonesia. Education is essential for producing sufficient human resources in forensic linguistics. The establishment of a forensic linguistics institute is necessary to develop the science itself. The institute will become a forensic linguistics development laboratory as well as the unveiling of that science with the prevailing legal system in Indonesia.

3. There needs to be an initiation of establishing the Indonesian Forensic Linguistics Institute which has a legal basis and authority in solving legal cases in Indonesia.

4. After examining the value of the usefulness of forensic linguistics learning in universities, especially as the provision of graduate profession choice, it should be followed up by the basic preparation of the substance of forensic linguistic learning materials.

\section{REFERENCES}

Asher, Ronald E. Encyclopedia of Language and Linguistics. Vol.3, pp.12 
10- 13. Oxford: Pergamon Press.

Bachari, Andika Dutha. Analisis Pragmatik terhadap Tindak Tutur yang Berdampak Hukum. Laporan Penelitian. Bandung: UPI.

Clark, Herbert H. and Thomas B. Carlson. 1982. Hearers and speech act. Language 58:332-73.

Gibbons, John, and M. Teresa Turell (eds). 2008. Dimensions of Forensic Linguistics. Amsterdam: John Benjamins.

Gibbons, J. 2003. Forensic Linguistics: an Introduction to Language in the Justice System. Blackwell.

Gibbons, John., V Prakasam, K V Tirumalesh, and H Nagarajan (eds). 2004. Language in the Law. New Delhi: Orient Longman.

Grice, H. P. 1975. Logic and conversation. Syntax and Semantics 3: Speech Acts, ed. by Peter Cole and Jerry L. Morgan, pp41-58. New York: Academic Press. Reprinted in Grice 1986.

Kurnia, Rizal Agung. 2013. Dialektika Folklor dengan Linguistik Forensik: Sebuah Romantisme Akademis. Makalah. Surabaya: Unair.

Kushartanti, Untung Yuwono and Multamina RMT Lauder. 2005. Pesona Bahasa Langkah Awal Memahami Linguistik, pp220-241. Jakarta: PT. Gramedia Pustaka Utama.

Leech, G. 1983. Principles of Pragmatics. New York: Longman Group Limited.

Nurhidayatulloh. 2013. Perkawinan di Bawah Umur Perspektif HAM-Studi Kasus di Desa Bulungihit, Labuhan Batu, Sumatra Utara. Al-Mawarid, p1-14.

Olsson, John. 2008. Forensic Linguistics: Second Edition. London: Continuum.

Searle, J.R. 1969. Speech Acts. London: Cambridge University Press.

Shuy, Roger W. 2001. Discourse Analysis in the Legal Context. In The Handbook of
Discourse Analysis. (eds) Deborah Schiffrin, Deborah Tannen, and Heidi E. Hamilton. Oxford: Blackwell Publishing. pp. 437-452.

Silalahi, Ronald Maraden Parlindungan. 2012. Peran Frekuensi Formant sebagai Penanda Identitas: Sebuah Formulasi fitur Fonetis Eksperimental untuk Kepentingan Forensik Akustik. Artikel.

\section{WORLD WIDE WEB}

http://pikiran-rakyat.com/node/156303

Ginting, Wahyu Adi Putra. Mana Di Mana Linguis(tik) Forensik Kita? 19 Maret 2012 http://lidahibu.com/2012/03/19/mana-dimana-linguistik-forensik-kita. [retrieved: January 30, 2015].

Hutasoit, Moksa. 2011. KPK Hadirkan Ahli Linguistik dalam Sidang Suap Anggota KPU.

https://news.detik.com/berita/1795720/kpkhadirkan-ahli-linguistik-dalam-sidang-suapanggota-kpu. [retrieved: January 27, 2015].

Nugroho. 2016. Peran Linguistik Forensik. http://id.shvoong.com/law-andpolitics/criminal-law/2278934-peranlinguistik-forensik/\#ixzz1uAUVGUDF. [retrieved: January 30, 2015].

Santosa, Eddi. Mahasiswa RI Temukan sistem Verifikasi Suara untuk Forensik. https://news.detik.com/berita/d1974055/mahasiswa-ri-temukan-sistemverifikasi-suara-untuk-forensik. [retrieved: July 25, 2012]

Tempo. 2014. Bercanda di Grup Internet, Pegawai Ini Diadili.

http://www.tempo.co/read/news/2014/12/26 /058630981/Bercanda-di-Grup-Internet-

Pegawai-Ini-Diadli. [retrieved: January 27, 2015]. 